\title{
IbM PETANI KETIMUN JEPANG DI KELURAHAN KOLONGAN TOMOHON
}

\author{
Aser Yalindua \\ Program Studi Pendidikan Biologi, Fakultas Matematika dan Ilmu Pengetahuan Alam, \\ Universitas Negeri Manado (UNIMA) \\ aseryalindua60@gmail.com
}

\begin{abstract}
Abstrak
Pengabdian masyarakat untuk IbM Petani Ketimun Jepang dilaksanakan di Kelurahan Kolongan Kota Tomohon Sulawesi Utara. Kegiatan pengabdian ini dilakukan dengan tujuan utama IbM Petani Ketimun Jepang di Kelurahan Kolongan Tomohon untuk memanfaatkan lahan-lahan kosong dari penduduk yang tidak diolah dan untuk mengembangkan usaha yang sudah ada dengan beberapa sentuhan teknologi pertanian yang dapat mengurangi biaya awal pengembahan lahan. Tujuan khusus yang ingin dicapai dalam kegiatan ini yaitu: 1) Terbangunnya kerjasama antar anggota kelompok tani ketimun jepang secara berkesinambungan yang merupakan wujud pelaksanaan kearifan lokal budaya mapalus; 2) Tertularnya pengetahuan kepada kelompok tani tentang cara bercocok tanam ketimun jepang; 3) Terjalinnya kerjasama antara perguruan tinggi dengan kelompok mitra yaitu petani ketimun jepang terutama pembinaan keterampilan bercocok tanam. Pada kegiatan ini kelompok tani secara bersama-sama mengolah lahan kosong untuk ditanami ketimun jepang. Metode pelaksanaan kegiatan terdiri dari beberapa tahap yaitu : Persiapan lahan, semai bibit, penanaman bibit, pemasangan tiang bambu, pemasangan tali nilon/kawat rambat ketimun jepang, dan penyiangan. Kegiatan ini telah memberikan manfaat terbangunnya kerjasama antar anggota kelompok tani ketimun jepang secara berkesinambungan yang merupakan wujud pelaksanaan kearifan lokal budaya mapalus; memberikan dampak tertularnya pengetahuan dan menambah wawasan perpikir kepada kelompok tani tentang cara bercocok tanam ketimun jepang; dan sudah memberikan manfaat terjalinnya kerjasama antara perguruan tinggi dengan kelompok mitra yaitu petani ketimun jepang terutama pembinaan keterampilan bercocok tanam.
\end{abstract}

Kata Kunci: Ketimun jepang, kelompok tani, Kolongan.

\section{PENDAHULUAN}

Kota Tomohon sebelum tahun 2003 merupakan salah satu kecamatan di Kabupaten Minahasa. Letaknya berada pada $1^{\circ} 15^{\prime}$ Lintang Utara dan $124^{\circ} 50^{\prime}$ Bujur Timur pada di ketinggian kira-kira 700-800 meter dari permukaan laut (dpl). Diapit oleh dua gunung berapi aktif, yaitu Gunung Lokon (1.689 m) dan Gunung Mahawu (1.311 m) dengan luas wilayah sekitar 11.420 Ha. Cuaca: $2{ }^{\circ} \mathrm{C}$ dan kelembapan 67\%. Jumlah penduduk: 93.857 (2012).
Suhu di Kota Tomohon pada waktu siang mampu mencapai 30 derajat Celsius dan 2324 derajat Celsius pada malam hari.

Kelurahan Kolongan Tomohon terletak di Wilayah Kecamatan Tomohon Tengah Kota Tomohon Sulawesi Utara. Secara geografis, kelurahan Kolongan terletak di sisi Barat Kota Tomohon dengan luas wilayah keseluruhan 155 ha dan berada di ketinggian antara 784-792 dpl, dengan jumlah penduduk adalah 2666 orang yang terdiri dari 1297 laki-laki dan 1369 
perempuan (Sumber : Kecamatan Tomohon Tengah Dalam Angka 2016). Kepadatan Penduduk 702 (jiwa/km2) .

Dalam perekonomian, dahulu Tomohon dikenal sebagai pusat produsen sayursayuran, kini predikat itu telah beralih ke Kecamatan Modoinding, Kabupaten Minahasa Selatan. Tomohon kini dikenal sebagai produsen bunga (kembang) di Provinsi Sulawesi Utara. Walaupun Tomohon sekarang di kenal sebagai "kota bunga" namun sejujurnya masyarakat tidak dapat hidup dari usaha bercocok tanam bunga, melainkan masih mengandalkan usaha bercocok tanam tanaman hortikultura terutama sayur-sayuran. Produksi sayur-sayuran dari Tomohon di pasarkan ke luar daerah khususnya di Papua, Gorontalo, Ternate, Sanger dan Talaud serta di Sulawesi Tengah dan banyak daerah lainya.

Salah satu potensi masyarakat Kota Tomohon khusunya di kelurahan Kolongan sama seperti masyarakat Minahasa pada umumnya memiliki adat istiadat dan budaya yang dikenal dengan sebutan mapalus. Budaya mapalus atau kerja gotong-royong telah berakar dan membuda-ya di kalangan masyarakat Minahasa. Budaya tersebut sampai saat ini masih terjaga dan terpelihara dalam kehidupan sosial. Bentuk mapalus di Kelurahan Kolongan diwujudkan dalam berbagai kegiatan seperti sosial duka dan kegiatan lainnya yaitu kelompok tani yang diberi nama kelompok tani "Abraham" yang melakukan kegiatan usaha bercocok tanam ketimun jepang atau labu siam (Sechium edule, bahasa Inggris: chayote) adalah tumbuhan suku labu-labuan (Cucurbitaceae) yang dapat dimakan buah dan pucuk mudanya. Tumbuhan ini merambat di tanah atau agak memanjat dan biasa dibudidayakan di pekarangan. Buah menggantung dari tangkai. Daunnya berbentuk mirip segitiga dan permukaannya berbulu. Produksi ketimun jepang di Tomohon selama tiga tahun yaitu: Tahun 2013 sebanyak 1858,00 ton, Tahun 2014 ton sebanyak 2510,00 ton dan Tahun 2015 sebanyak 1154,80 ton.

Produksi ketimun jepang cukup tinggi dalam persatuan luas areal. Informasi dari bapak Martinus Wiliam dan bapak Daniel Rau yang pernah bercocok tanam ketimun jepang bahwa luas areal $4 \times 5 \mathrm{~m}$ dapat menghasilkan 1 karung (50 kg) buah ketimun sebagaimana Gambar 4 berikut. Harga ketimun jepang di Tomohon per karung berkisar antara $\mathrm{Rp}$ 50.000-Rp 100.000. Buah ketimun dipanen setiap minggu selama 3-4 tahun (Bapak Max Kalalo seorang penampung buah ketimun jepang). Lahan kebun ketimun jepang seluas 1 ha dapat diperoleh 400 petak (4 x $5 \mathrm{~m}$ ) setara dengan 400 karung ketimun jepang. Jika harga minimal Rp 50.000/karung maka luas 1 ha kebun diperoleh 400 x Rp 50.000 $=\operatorname{Rp} 20.000 .000 /$ minggu. Dalam 1 bulan diperoleh hasil Rp 80.000.000. Dalam setahun dapat diperoleh hasil Rp 960.000.000. Jika harganya maksimal maka hasilnya dua 
kali lipat. Hasil ini cukup untuk meningkatkan penghasilan anggota kelompok tani.

Permasalahan utama yang ada di kelurahan kolongan yaitu: 1) Kecenderungan kerja individualistis yang sudah mulai menggeser budaya mapalus dapat diminimalisir dengan kerja sama kelompok; 2) Memperoleh teknologi sederhana yang dapat menekan biaya melalui penggunaan kawat sebagai pengganti sebagian bahan bambu yang sudah mulai sulit diperoleh; 3) Anggota kelompok tani mempunyai penghasilan tetap untuk membiayai kehidupan keluarganya.

Tujuan yang ingin dicapai dalam kegiatan ini yaitu: 1) Terbangunnya kerjasama antar anggota kelompok tani ketimun jepang secara berkesinambungan yang merupakan wujud pelaksanaan kearifan lokal budaya mapalus. 2) Tertularnya pengetahuan kepada kelompok tani tentang cara bercocok tanam ketimun jepang. 3). Terjalinnya kerjasama antara perguruan tinggi dengan kelompok mitra yaitu petani ketimun jepang terrutama pembinaan keterampilan bercocok tanam.

\section{METODE PELAKSANAAN}

Metode pelaksanaan kegiatan terdiri dari beberapa tahap yaitu: 1) Persiapan lahan; 2) Persiapan bibit; 3) Pengolahan tanah; 4) Penanaman bibit; 5) Pemasangan tiang bambu; 6) Pemasangan kawat rambat tanaman ketimun jepang; dan 7) Penyiangan tahap awal. Lahan seluas $50 \mathrm{x}$
$40 \mathrm{~m}$ yang tidak diolah menjadi sasaran lokasi kegiatan dibersihkan dengan peralatan sederhana seperti parang dan cangkul.

Setelah semuanya siap selanjutnya dilakukan penanaman bibit yang sudah cukup matang pada lahan yang sudah dipersiapkan. Kegiatan selanjutnya penyiapan bahan bambu yang digunakan sebagai sebagai tiang penyangga. Tiang bambu dipasang pada jarak $5 \mathrm{~m}$. Lahan seluas 50 x $40 \mathrm{~m}$ meter dipasang tiang bambu sebanyak 120 . Antar tiang bamu dihubungkan dengan kawat sebagai tempat merambatnya tanaman ketimun jepang.

\section{HASIL DAN PEMBAHASAN}

Kegiatan ipteks bagi masyarakat petani ketimun jepang telah dilakukan dengan kegiatan antara lain persiapan berupa pertemuan dengan anggota kelompok seperti pada gambar 8. Dalam diskusi dengan anggota kelompok diketahui bahwa mereka umumnya sudah sangat berpengalaman mengelola kebun ketimun jepang. Oleh karena itu tidak perlu dilakukan penyuluhan atau pelatihan tetapi diperlukan penguatan modal usaha untuk menambah luas areal yang sudah ada, serta sentuhan teknologi sederhana yang dapat mengurangi modal usaha untuk jangka waktu tertentu.

Kegiatan diskusi persiapan menyangkut kesiapan lahan dan bibit. Lahan yang digunakan adalah lahan tidur yang sudah beberapa tahun tidak diolah milik 
masyarakat yang tinggal di luar daerah kemudian disewa oleh anggoata kelompok.

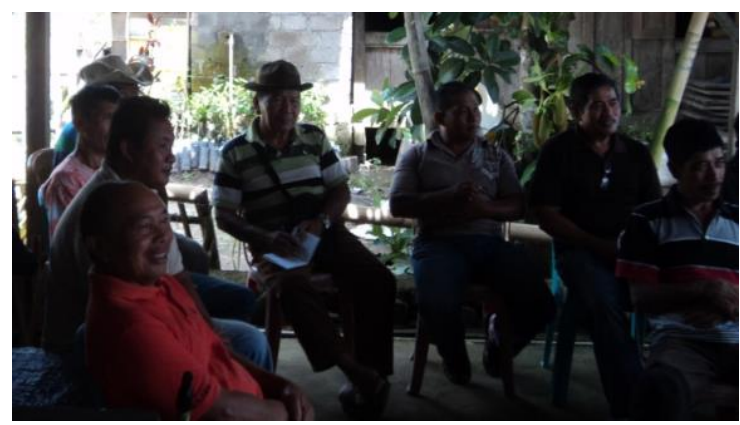

Gambar 1. Suasana diskusi persiapan lahan dan bibit.

Materi yang disampaikan dalam diskusi persiapan adalah persiapan lahan dan bibit serta penerapan teknologi sederhana berupa penggunaan kawat untuk mengganti sebagian bahan yang biasa terbuat dari bambu. Dalam diskusi tersebut banyak tanggapan dari peserta terutama tentang penggunaan teknologi sederhana berupa penggunaan kawat yang menurut mereka tidak bisa digunakan karena jika pada musim panas kawat tersebut menjadi panas dan akan menghanguskan batang ketimun yang sedang melilit pada masa awal pertumbuhan. Diputuskan bahwa untuk menggantikan kawat digunakan tali nilon (tali jemuran). Untuk kedepannya kawat akan digunakan setelah ketimun mulai berprodukasi dengan maksud pemasangan kawat pada saat itu sudah terlindungi oleh tanaman yang sudah menjalar sehingga fungsinya hanya sebagai penunjang saat buahnya sudah membesar.

Ketimun jepang dapat tumbuh baik di daerah tinggi maupun dataran rendah. Di daerah pegunungan seperti Tomohon adalah tempat yang di sukai oleh tanaman ketimun jepang karena berhawa dingin dan lembab. Tanah untuk menanam tumbuhan ini harus banyak mengandung air, subur, gembur dengan $\mathrm{pH}$ tanah sekitar 5 hingga 6 . Waktu penanaman ketimun jepang yang tepat yaitu pada akhir musim penghujan sekitar Maret atau April. Kegiatan pertama yang dilakukan oleh kelompok adalah persiapan bibit yang sudah benar-benar matang yang akan disemai lebih dahulu menggunakan polybag atau pot sebagaimana gambar 2 .
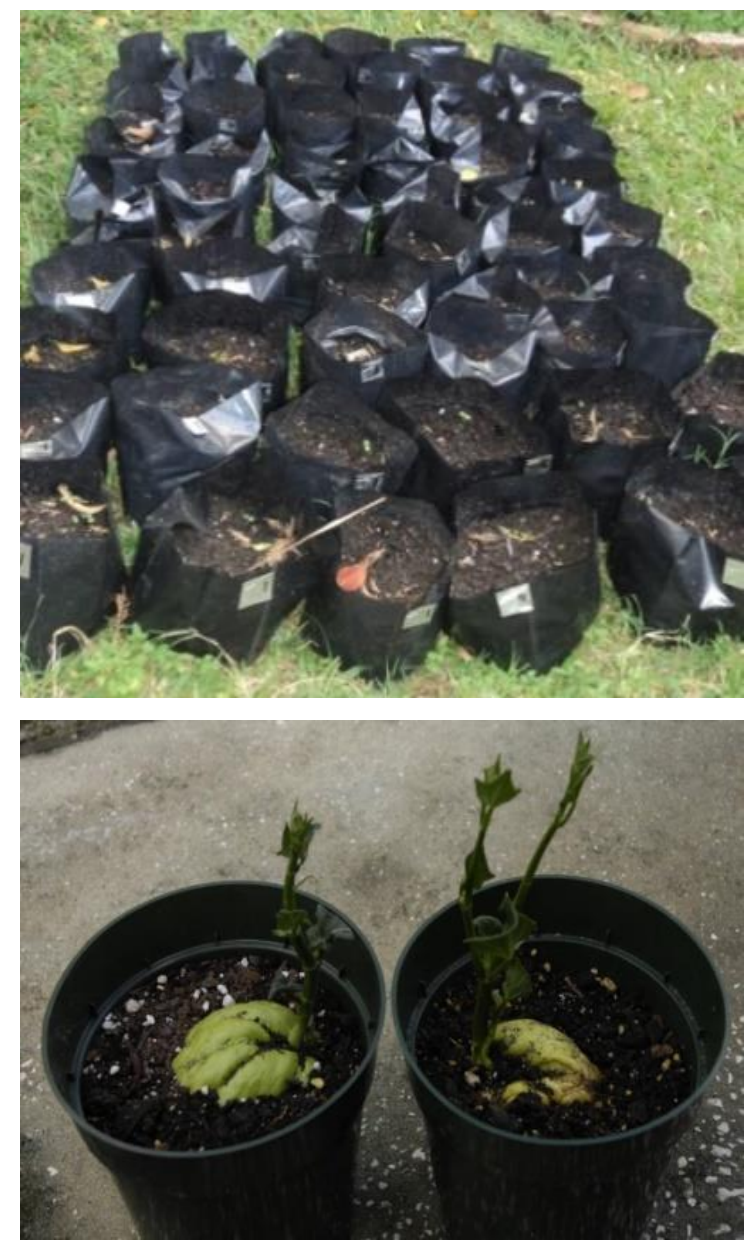

Gambar 2. Bibit ketimun disemai. 
Pembibitan dilakukan dengan cara menggunakan buah ketimun jepang yang sudah tua. Caranya buah sudah tua di petik lalu disemai ditempat teduh hingga bertunas. Jika tunas sudah mencapai panjang sekitar 10 hingga $20 \mathrm{~cm}$ dengan daun 3-4 helai baru dapat di pindah ke lahan tanam. Menunggu bibit semai bertumbuh lahan kebun mulai dibuka oleh anggota kelompok. Bibit yang disemai setelah bertumbuh akan dipindahkan ke lahan yang sudah disiapkan seperti gambar 3. Lahan yang akan di tanami tanaman ketimun jepang harus di buat lubang dahulu dengan ukuran $50 \mathrm{~cm}$ untuk lebarnya dan $40 \mathrm{~cm}$ untuk dalamnya. Jarak antar lubang sekitar 3 meter dengan jarak antar baris sekitar 5 meter, kemudian setiap lubang diberi pupuk kandang atau kompos di dasarnya.

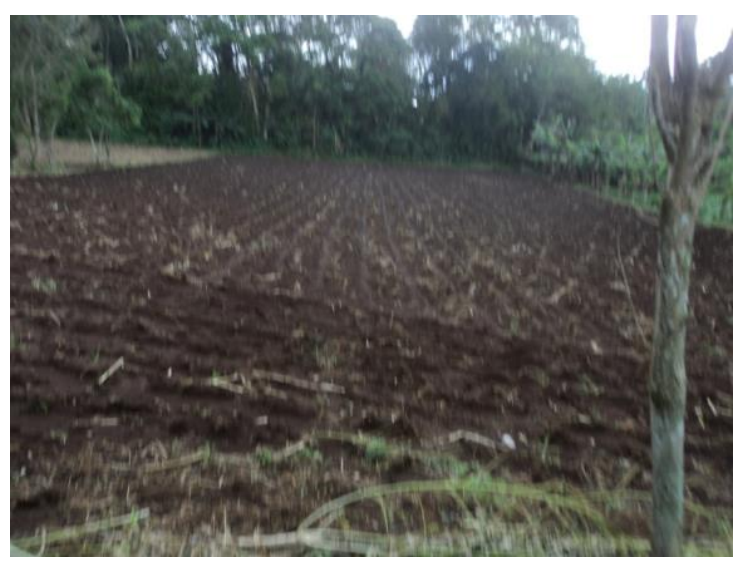

Gambar 3. Lahan kebun ketimun siap ditanami.

Setelah tiga bulan ketimun mulai berbuah namun pemasangan kawat belum dilakukan karena bambu yang dipasang lebih dahulu masih cukup kuat. Kawat akan dipasang kemudian setelah satu tahun pada saat bambu sudah mulai rusak. Dari pengamatan bahwa pemasangan kawat akan efektif dalam jangka waktu yang lama sampai 5 tahun. Jika menggunakan bambu setiap tahun harus diganti sebab tanaman ketimun jepang dapat berproduksi sampai 5 tahun. Dalam pertumbuhan ketimun jepang perlu adanya pemangkasan agar tumbuh tunas-tunas baru yang lebih banyak dan kemudian berbunga berbuah lebih banyak.
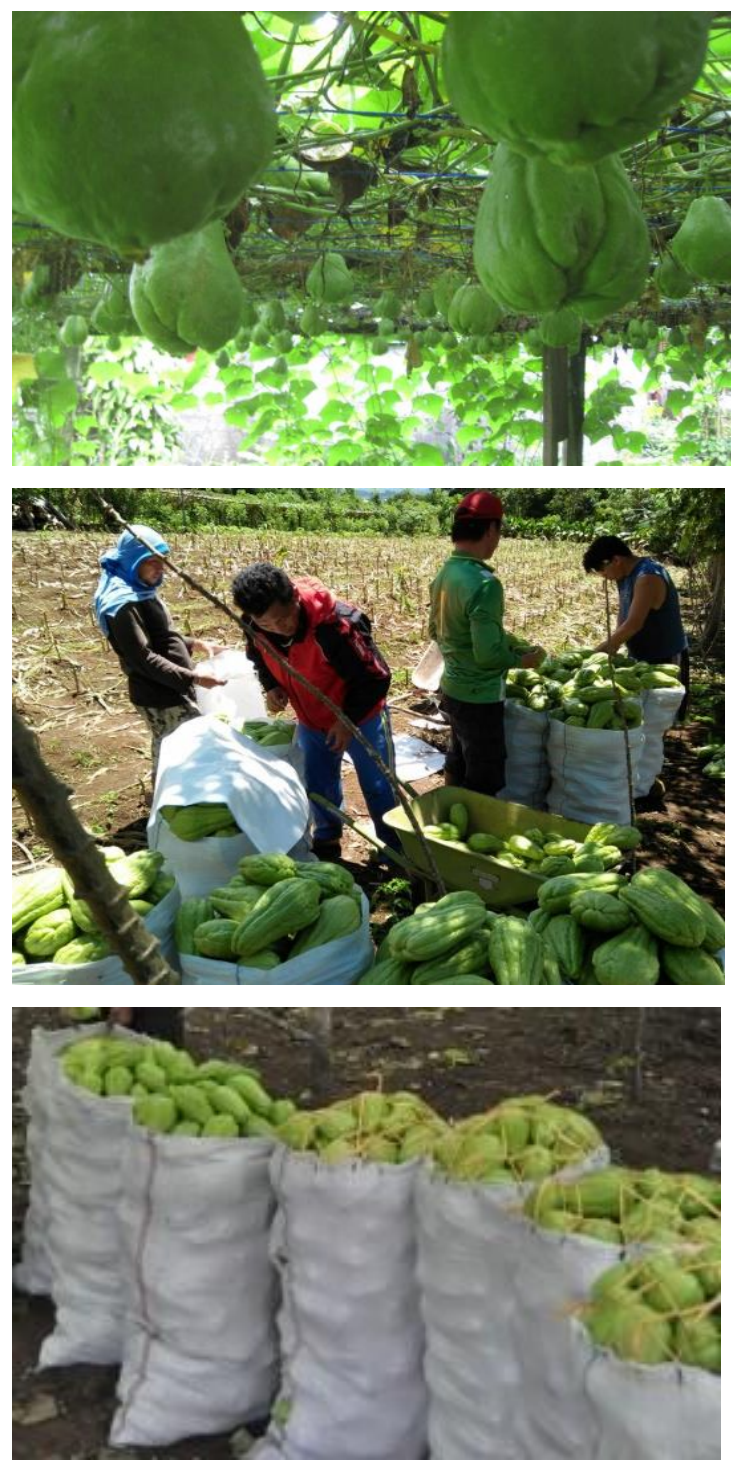

Gambar 4. Kelompok tani panen buah ketimun jepang. 


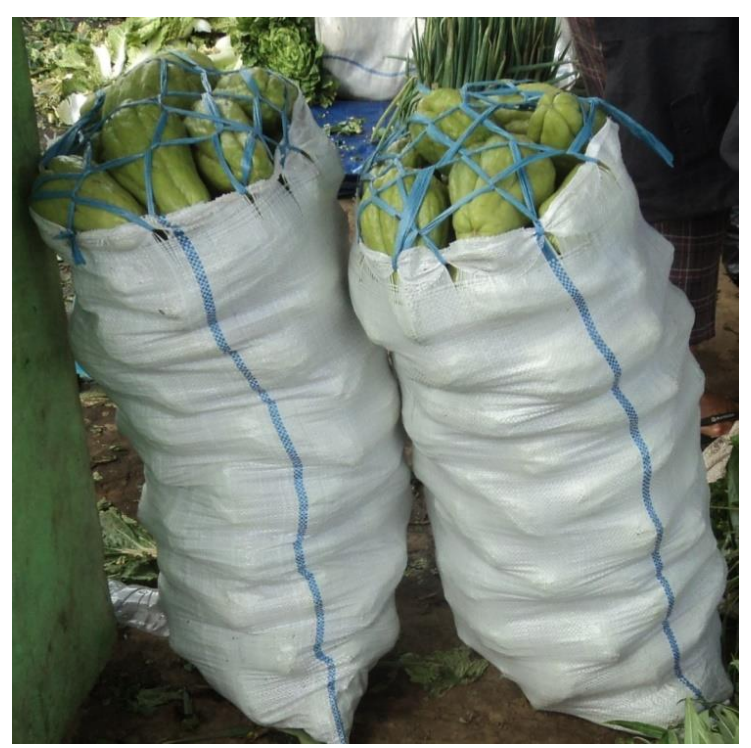

Gambar 5. Buah ketimun jepang di jual ke pasar oleh anggota kelompok tani dengan harga $\mathrm{Rp}$. 100.000 per karung.

Petani di Kelompok tani Abraham mempunyai motivasi dan keinginan yang lebih besar tentang pengolahan ketimun jepang. Keinginan petani untuk maju bersamabersama terutama dalam mensejahterakan keluarganya tidak terlepas dari peranan kelompok tani yang mereka bangun. Hal ini terlihat dari adanya keinginan untuk mengembangkan usaha menambah lahan yang mereka kelalola. Kelompok tani Abraham kelurahan Kolongan merasa pengetahuan tentang pengolahan ketimun jepang ini sangat baik karena banyaknya hal yang mereka dapatkan dari kegiatan ini. Pemanfaatan tali atau kawat sebagai media melilitkan tanaman ketimun jepang mereka tidak pernah pikirkan bahwa pemanfaatan dalam waktu lama sangat menguntungkan baik bahan maupun tenaga. Hasil panen ketimun jepang di Tomohon telah dipasarkan ke luar daerah khususnya di bagian timur Indonesia seperti Papua dan Ternate serta beberapa daerah lain seperti Gorontalo, Kepulauan Sangihe dan Talaud.

Kegiatan ini sudah mewujutkan visi dan misi UNIMA menjadi pusat unggulan khususnya dalam berkompetitif dan berinovatif dalam penelitian dan pengabdian pada masyarakat. Secara langsung UNIMA telah memberikan manfaat pengetahuan dan peningkatan kesejahteraan serta kerjasama kepada masyarakat khusunya anggota kelompok tani ketimun jepang sebagai mitra.

Berdasarkan kondisi yang ada di wilayah Kelurahan Kolongan, maka dibuat suatu rencana pengembangan agribisnis ketimun jepang dalam jangka pendek, menengah dan panjang. Dalam jangka pendek perlu dilakukan melalui pembinaan secara berkelanjutan guna meningkatkan produktivitas kelompok tani. Dalam jangka menengah perlu menumbuhkan industri-industri rumah tangga pengolahan ketimun jepang. Dalam jangka panjang perlu mengupayakan pembangunan subterminal agribisnis sebagai pusat agribisnis petani kelurahan Kolongan.

Berdasarkan analisa usaha kelompok tani secara deskriptif dapat diketahui bahwa produk bahwa pemanfaatan tali nilon atau kawat sebagai tempat menjalar ketimun jepang selama 4-5 tahun cukup layak dikembangkan. Perlu pula rencana pengembangan produk olahan ketimun jepang dengan melakukan pembinaan secara berkelanjutan, penumbuhan industri rumah tangga dan pembangunan sub terminal agribisnis. 


\section{KESIMPULAN}

Melalui kegiatan pengabdian pada UCAPAN TERIMA KASIH

masyarakat ini, dapat disimpulkan bahwa:

Terima kasih disampaikan kepada Lembaga

1) Kegiatan ini telah memberikan manfaat Penelitian dan Pengabdian Masyarakat terbangunnya kerjasama antar anggota kelompok tani ketimun jepang secara berkesinambungan yang merupakan wujud pelaksanaan kearifan lokal budaya mapalus;

2) Kegiatan ini telah memberikan dampak tertularnya pengetahuan dan menambah wawasan perpikir kepada kelompok tani tentang cara bercocok tanam ketimun jepang; dan

3) Kegiatan ini sudah memberikan manfaat terjalinnya kerjasama antara perguruan tinggi dengan kelompok mitra yaitu petani ketimun jepang terutama pembinaan keterampilan UNIMA yang sudah membiayai kegiatan pengabdian ini melalui dana PNBP tahun 2017.

\section{KEPUSTAKAAN}

BPS Kota Tomohon (2013). Produksi sayuran Kota Tomohon.

Daniel Rau (2016). Komunikasi Pribadi https://id.wikipedia.org/wiki/Kota_Tomoh on

http://www.g-excess.com \& http://kiathidupsehat.com

health.kompas.com/read/2010/03/17/093 84184/Labu.Siam.Redam.Hipertensi

Martinus William Poluan (2016). Komunikasi Pribadi bercocok tanam. 
Jurnal ABDIMAS, Vol. 11, No. 2, Agustus 2018

ISSN: 1979-0953 | e-ISSN: 2598-6066 